\title{
Fig 57
}
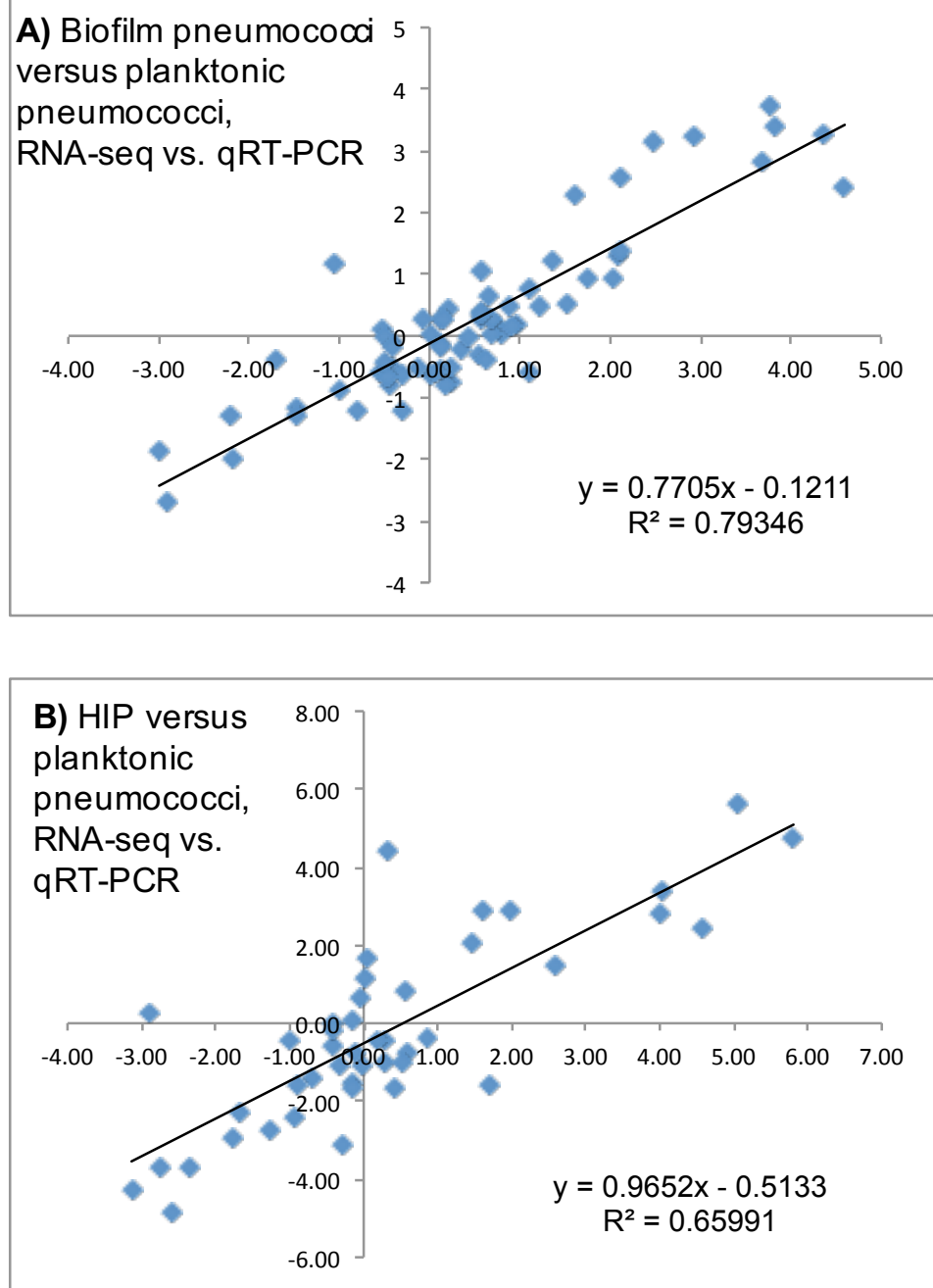

\section{C) BIP versus}

planktonic pneumococci, RNA-seq vs. qRT-PCR

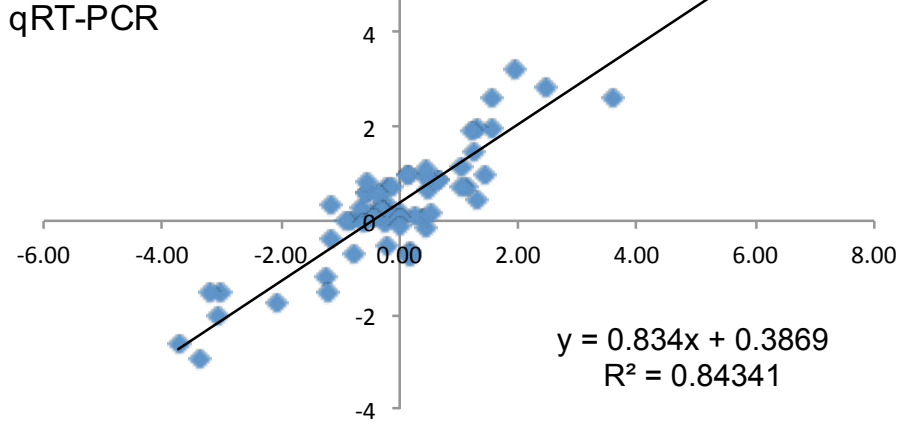

